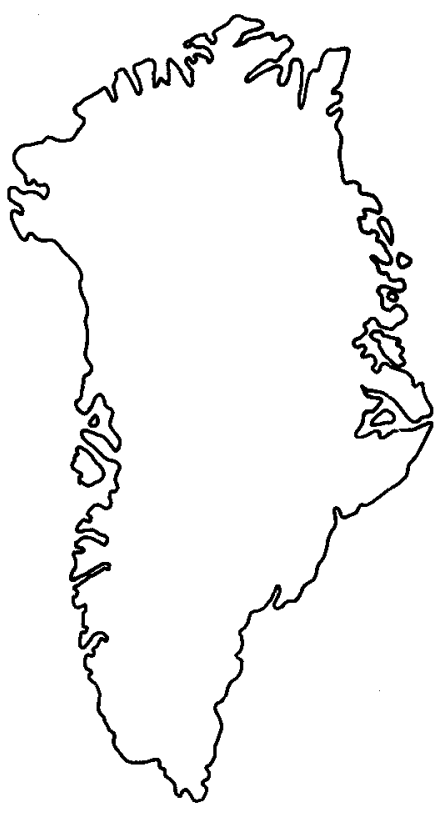

\title{
Thermal maturity history of the Upper Permian succession in the Wegener Halvø area, East Greenland
}

\author{
Flemming G. Christiansen, Stefan Piasecki \\ and Lars Stemmerik
}

\begin{abstract}
The Upper Permian succession, which is considered the most interesting exploration target in Jameson Land, is thermally postmature in the Wegener Halv $\emptyset$ area, in contrast to the exposed immature sediments along the western margin of the Jameson Land basin and further north between Traill $\emptyset$ and Wollaston Forland. Ranking based on $T_{\max }$, Hydrogen Index, $\mathrm{R}_{\mathrm{o}}, \mathrm{GC}$ and IR data points to a rather constant thermal maturity throughout most of Wegener Halvø (in the upper wet gas zone) with lower maturity towards the south-west in Devondal (in the lower oil zone). The relatively uniform maturity pattern, combined with known thickness of overlying sediments, suggests that regionally increased heat flow in the Tertiary related to the break-up of the North Atlantic, controls the maturity.
\end{abstract}

F. G. C., S. P. \& L. S., Geological Survey of Greenland, Øster Voldgade 10, DK-1350 Copenhagen K, Denmark.

The Upper Permian is considered as the most important target in the ongoing exploration in Jameson Land, East Greenland (e.g. Surlyk et al., 1984b, 1986a,b), and studies of the thermal history of the prolific oil-prone source rocks within the Ravnefjeld Formation are hence of great importance in prospect evaluation.

Most exposures of the Upper Permian succession along the western margin of the Jameson Land basin and on Traill $\varnothing$, Gauss Halvø, Hold with Hope, Clavering $\varnothing$ and Wollaston Forland towards the north are thermally immature or occasionally have reached onset of petroleum generation during burial. Only sediments in the vicinity of Tertiary intrusions display higher maturities (Surlyk et al., 1984b, 1986a,b).

The initial studies and sampling for the present analytical work were carried out in the late 1970s (Stemmerik, 1982) and were followed by oil-related studies with extensive shallow core drilling in 1982, 1983 and 1988 (Surlyk, 1983; Surlyk et al., 1984a; Christiansen \& Stemmerik, 1989).

Previously obtained, but mostly unpublished, data suggested that the Upper Permian of Wegener Halvø is postmature with respect to petroleum generation, but these early studies were generally not accompanied by any detailed maturity ranking or suggestions of regional gradients and possible thermal history.

Along the eastern basin margin exposures of uplifted, previously deeply buried, Upper Permian sediments are restricted to Wegener Halvø, north-east of Jameson Land. This area has consequently been chosen for studies of the diagenetic history and reservoir potential of the Upper Permian carbonates (Stemmerik et al., 1989; Christiansen \& Stemmerik, 1989).

The aim of the present paper is to synthesise all maturity data and newly measured infrared results to obtain a more detailed picture of the maturity pattern and thermal history of Wegener Halvø.

\section{Geological setting}

The Wegener Halv $\varnothing$ area formed a structural high during Carboniferous and Early Permian times, and folded Devonian strata are unconformably overlain by Upper Permian conglomerates and carbonates. This pattern continued into the Late Permian and the area became the site of abundant bryozoan build-ups which pass into basinal shales towards the west (Surlyk et al., 1986a; Hurst et al., 1989).

The Upper Permian carbonates were fractured, and subsequently cemented by ferroan calcite cement, during a late hydrothermal event during which baryte, flourite, galena and quartz were also precipitated (Harpøth et al., 1986; Surlyk et al., 1986a). This event post-dates hydrocarbon migration into the build-ups; isotopic data from the calcite cement and fluid inclusion data from the associated flourite and quartz indicate formation 
temperatures of $115-150^{\circ}$. This hydrothermal event is recognised throughout Wegener Halvø with the highest intensity along major faults and generally waning importance towards the south-west.

The few available fission track data from the area indicate that immediately after heating there was a rather rapid uplift through the $100^{\circ} \mathrm{C}$ isotherm approximately $20 \mathrm{Ma}$ ago (Hansen, 1988). This suggests a Tertiary age for the cementation and mineralisation of the build-ups.

\section{Material and methods}

The shallow cores GGU 303110 (Gråklint Beds, Gipsdalen Formation, Permdal), GGU 303118 (Ravnefjeld Formation, Devondal), GGU 303109 (Ravnefjeld Formation, Lille Cirkusbjerg), GGU 303106-303108 (Ravnefjeld Formation, 'Trappesøer'), and GGU 303132 (Schuchert Dal Formation, Paradigmabjerg) form the main basis for the analytical work, supplemented by surface samples from central and western Wegener Halvø, 'Trappesøer', Calamites Dal, and Para-

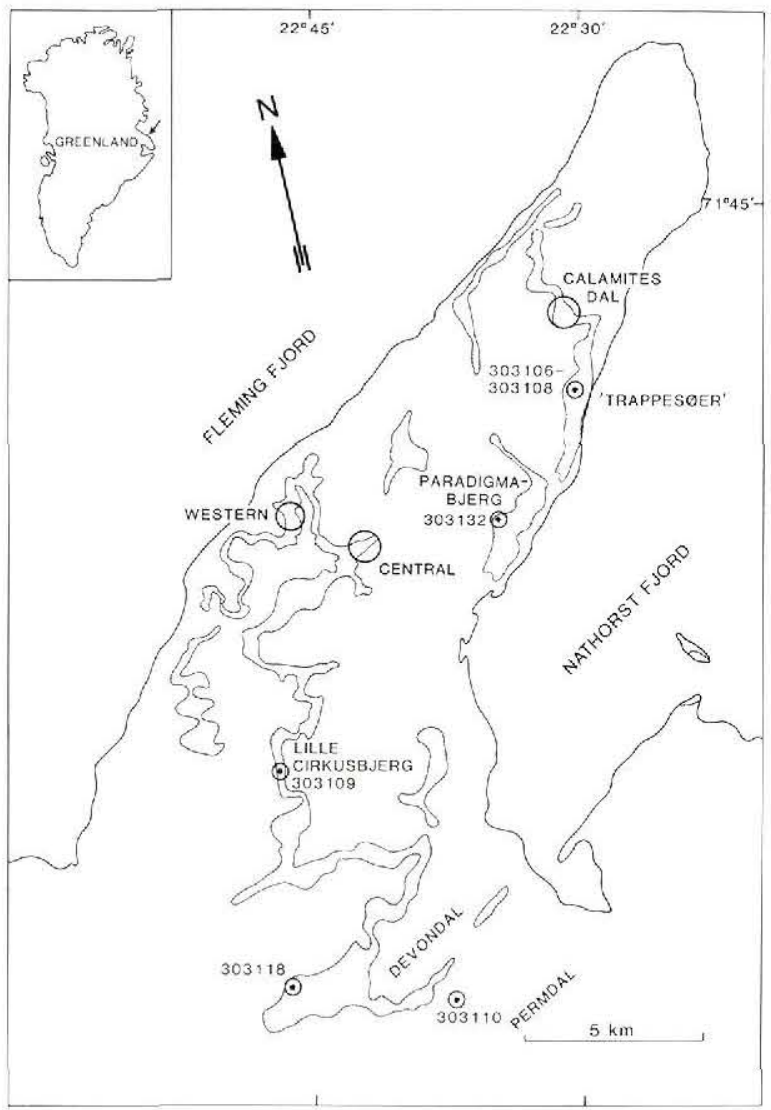

Fig. 1. Simplified geological map of Wegener Halvø showing the distribution of Upper Permian sediments (stippled) and the position of drill sites and sample localities.

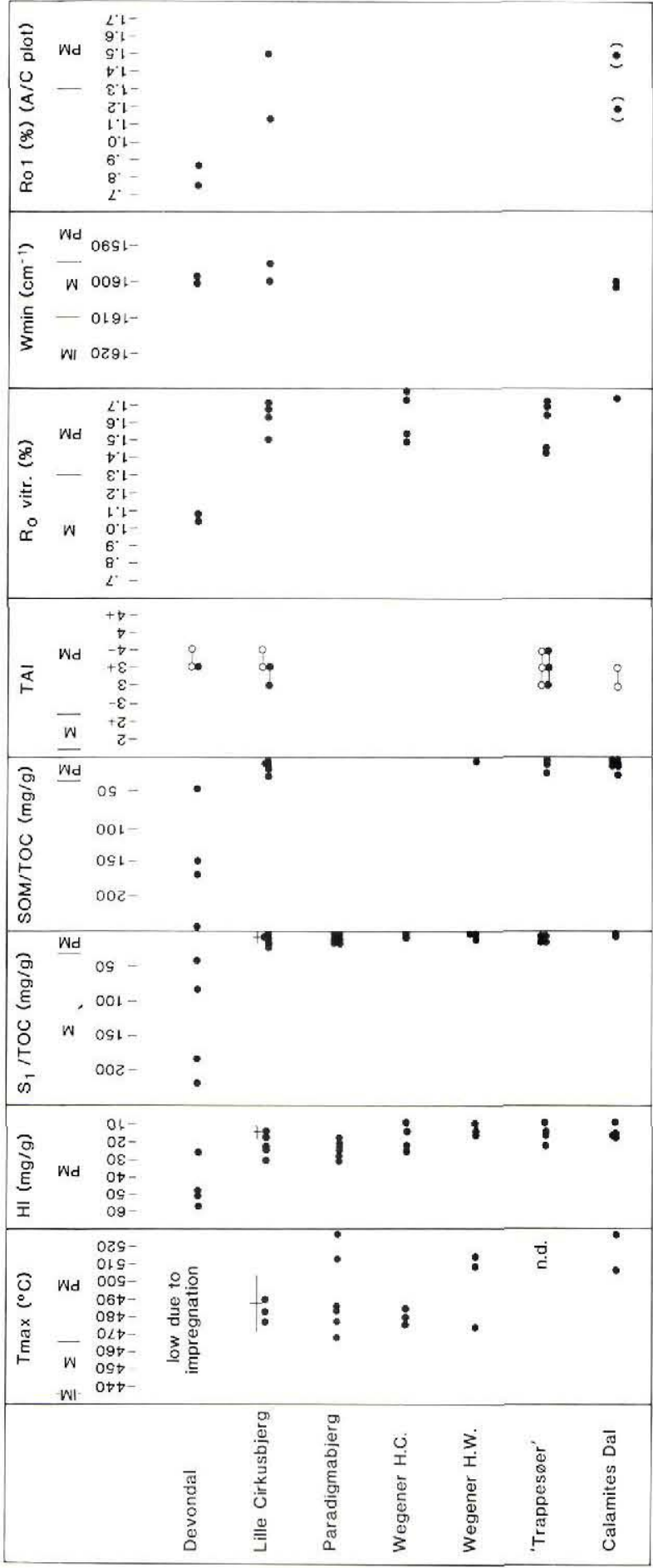

Fig. 2. Measured maturity parameters from Rock Eval pyrolysis, extraction, palynology, organic petrology and infrared spectroscopy. A tentative ranking with respect to petroleum generation is indicated for each parameter. Filled circles: Ravnefjeld Formation, open circles: Wordie Creek Formation. The bars indicate average values \pm 1 standard deviation from the detailed study of the Lille Cirkusbjerg core by Karlsen (1987). 
digmabjerg (fig. 1). Most of the material consists of dark, laminated organic-rich shales with TOC values averaging around $3 \%$. Measured parameters from samples with less than $0.5 \%$ TOC have been omitted.

The material was analysed by I.ECO/Rock Eval pyrolysis, vitrinite reflectance measurements, palynological studies and gas chromatography at the Geological Surveys of Greenland and Denmark (most data are reported by Piasecki, 1985, 1987 and Thomsen, 1985). The analytical procedures follow the description given by Christiansen et al. (1989). The infrared spectroscopy was carried out commercially by H. H. Ganz, Technical University of Berlin. The preparation, analytical techniques and parameters obtained are described in detail by Ganz \& Kalkreuth (1987, in press).

\section{Results}

Rock Eval pyrolysis. Rock Eval pyrolysis provides three parameters that are important for ranking of maturity within the study area: the $T_{\max }$ value, the Hydrogen Index, and the relative content of hydrocarbons $\left(S_{1} /\right.$ TOC) (fig. 2).

All localities display average $T_{\max }$ values between $480^{\circ} \mathrm{C}$ and $520^{\circ} \mathrm{C}$ (fig. 2), with the exception of the Devondal core (GGU 303118) where $T_{\max }$ values are low and unreliable $\left(<400^{\circ} \mathrm{C}\right)$ due to bitumen impregnation. The Hydrogen Index, which expresses the residual potential of the kerogen, follows a similar variation with slightly higher average values in Devondal (HI $=46 \pm$ 14) compared to the very low and consistent values in all other arcas: Lille Cirkusbjerg $(14 \pm 4)$, central Wegener Halvø $(20 \pm 6)$, western Wegener Halvø $(13 \pm 2)$, Paradigmabjerg (24 \pm 4$)$, 'Trappesøer' $(15 \pm 5)$ and Calamites Dal $(15 \pm 4)$. The hydrocarbon content in the shales $\left(\mathrm{S}_{1} / \mathrm{TOC}\right)$ is very high in the Devondal core and low in all other cases (fig. 2).

The pyrolysis data obtained suggest that the Devondal area has reached a maturity corresponding to approximately the end of petroleum generation, without significant cracking to gas. All other localities are thermally more mature corresponding to the early stages of wet gas generation.

Gas chromatography. Measurements of extractability support the differences noted by the Rock Eval method. The extractability of the Devondal samples is very high (50 to $250 \mathrm{mg} \mathrm{SOM} / \mathrm{g}$ TOC) with saturated lrydrocarbons comprising between $70 \%$ and $80 \%$ of the soluble organic material. All other samples show very low extractabilities, typically less than $10 \mathrm{mg}$ SOM/g TOC (fig. 2 ), with less than $10 \%$ hydrocarbons in the extracts. The gas chromatograms of core GGU 303118 display typical
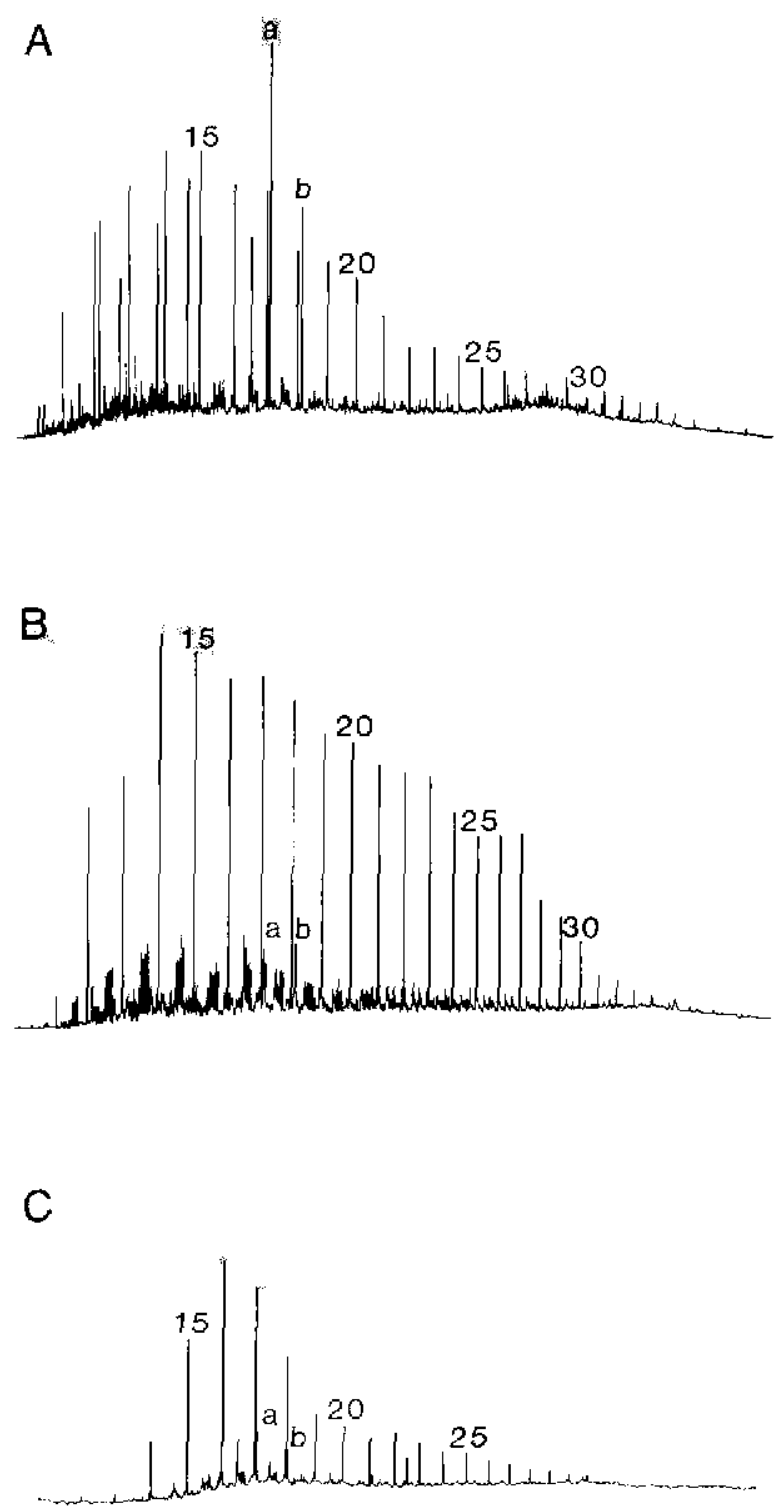

Fig. 3. Gas chromatograms of saturated hydrocarbons. a: pristane, b: phytane, numbers are $n$-alkane carbon numbers.

A. Typical immature Ravnefjeld Formation shalc from western Jameson Land (GGU 303213).

B. Typical mature Ravnefjeld Formation shale from the Devondal core (GGU 303118-18).

C. Typical postmature Ravnefjeld Formation shale from the Lille Cirkusbjcrg core (GGU 303109).

fcatures of mature source rocks with low $\mathrm{Pr} / n \mathrm{C}_{17}$ ratios, a smooth $n$-alkane distribution but still with relatively high contents of longer $n$-alkanes (fig. 3B). Other samples display characteristics typical of degraded and postmature source rocks with a $n$-alkane distribution biased towards short chains (fig. 3C). 
Thermal Alteration Index. Measurements of the Thermal Alteration Index (TAI) have been carried out by Piasecki $(1985,1987)$. This work includes data on the overlying Wordie Creek Formation which contains abundant spores and pollen in contrast to the Ravnefjeld Formation. The latter formation is exceptionally poor in sporomorphs in the Wegener Halvø region and therefore unsuitable for measurements of sporomorph colours (TAI). The material studied typically shows values around $3-3^{+}$(postmature; fig. 2), with only little regional variation and no specific lower maturity in the Devondal area.

Reflectance measurements. Measurements of reflectance of the organic material have been carried out by Thomsen (1985). Due to the low content of vitrinite sensu stricto in the Ravnefjeld Formation, reliable $\mathrm{R}_{\mathrm{o}}$ values are difficult to obtain. Most reflectograms contain relatively few measurements and intense scattering with several maxima. The recorded and interpreted $R_{o}$ values are between 1.0 and $1.1 \%$ in Devondal, and between 1.4 and $1.8 \%$ throughout the remaining area (fig. 2). The Devondal values may be too low due to bitumen impregnation of vitrinites, whereas the other values may be too high due to measurement of initial liptinic kerogen or bituminite. In the latter case, the reflectance range of 1.4 to $1.8 \%$ corresponds to a true vitrinite reflectance between 1.25 and $1.5 \%$, using the equation of Jacob (1985).

Infrared spectroscopy. Six samples (two core samples from Devondal, two core samples from Lille Cirkusbjerg, and two surface samples from Calamites Dal) were selected for studies of infrared absorbance spectra. A number of different parameters have been calculated from the absorbance spectra of kerogen concentrates (Ganz \& Kalkreuth, in press). For maturity evaluation, especially the intensity of the aliphatic bands compared to aromatic $\mathrm{C}=\mathrm{C}$ bands (A-factor) and carboxyl/carbonyl bands relative to aromatic $\mathrm{C}=\mathrm{C}$ bands ( $\mathrm{C}$-factor) are sensitive, but unfortunately easily affected by weathering. The position of the $\mathrm{C}=\mathrm{C}$ aromatic band changes towards lower minimum wave number with increasing maturation; in the present case the effect of weathering is of limited importance (Ganz \& Kalkreuth, in press).

The kerogen from Devondal clearly contains higher abundances of $\mathrm{CH}_{2}$ and $\mathrm{CH}_{3}$ aliphatic groups compared to that from Lille Cirkusbjerg and Calamites Dal, and plots close to the Type II evolutionary path in the A-C diagram (fig. 4; comparable to the $\mathrm{H} / \mathrm{C}$ vs $\mathrm{O} / \mathrm{C}$ van Krevelen diagram; $\mathrm{R}_{\mathrm{o}}=0.8$ to $0.9 \%$ ). The Lille Cirkusbjerg kerogen is also close to the type II curve,

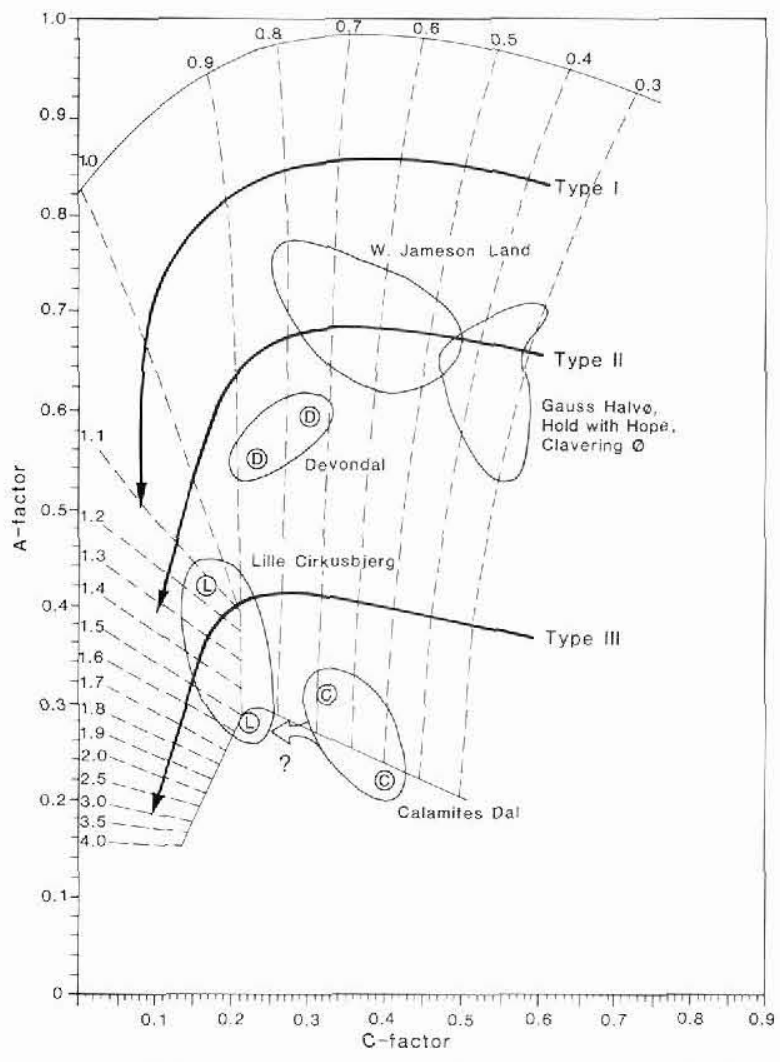

Fig. 4. A-C factor plot of samples from Devondal, Lille Cirkusbjerg and Calamites Dal with vitrinite reflectance equivalent grid. Modified after Ganz \& Kalkreuth (1987, in press). For comparison the distribution of immature to early mature Ravnefjeld Formation shaies from Gauss Halvø, Hold with Hope and Clavering $\varnothing$ is indicated $(n=12)$.

whereas the Calamites Dal samples seem oxygenated but probably have a similar maturity (between 1.1 and $1.5 \%$ equivalent $\mathrm{R}_{\mathrm{o}}$ ).

The minimum wave number shows only little variation between the three localities, and the values obtained between 1602 and $1595 \mathrm{~cm}^{-1}$ correspond to a vitrinite reflectance between 0.85 and $1.25 \%$.

\section{Maturity gradients and thermal history}

Although the maturity parameters measured are quite different in sensitivity and not always easily correlated and calibrated in terms of petroleum and gas generation, the data presented reveal a consistent maturity pattern. Most parameters indicate a slightly lower thermal maturity of the Ravnefjeld Formation in the Devondal core compared to all other localities, and most data are consistent with a position close to the end of petroleum generation before any significant cracking to 
gas at the time of deepest burial. In contrast, all other localities have a maturity corresponding to early wet gas generation, without any detectable lateral variations across Wegener Halvø.

The relatively uniform maturity of the Ravnefjeld Formation over distances of up to at least $15 \mathrm{~km}$ suggests that regional subsidence and/or regionally increased heat flow are the main factors in the maturity history, whereas local Tertiary intrusives (dolerite dykes or deep granites) have only little influence. This is confirmed by the maturity level of the Middle Triassic Gråklint Beds in core GGU 303110, $5 \mathrm{~km}$ ESE of Devondal and several hundreds of metres higher in the sequence, which corresponds approximately to peak generation.

On Wegener Halvø the Triassic succession is relatively thin $(<1 \mathrm{~km})$ compared to the remaining part of Jameson Land. Assuming a Jurassic and Cretaceous cover with a thickness similar to that of the Jurassic succession in northern Jameson Land plus the Cretaceous shales on Traill $\emptyset$, it is not likely that the Upper Permian sediments subsided through the upper boundary of the 'oil window' before the Late Cretaceous. The recorded high maturity, close to the lower boundary of the 'oil window' and into the wet gas zone, is consequently due to a rather thick Tertiary overburden (mainly basalts) or to increased heat flow related to Tertiary volcanism and break-up of the North Atlantic.

The local differences in maturity of the Ravnefjeld Formation between Devondal and the remaing part of Wegener Halvø are thought to be the result of an overprint from the regionally recognised hydrothermal event previously described. Thus the maturity history of the Ravnefjeld Formation in Devondal appears to be more representative for the subsurface part of the basin than the slightly higher maturity recognised elsewhere in Wegener Halvø.

\section{References}

Christiansen, F. G. \& Stemmerik, L. 1989: Shallow core drilling of Upper Permian and Upper Triassic - Lower Jurassic potential reservoir rocks in central East Greenland. Rapp. Grønlands geol. Unders. 145, 79-84.

Christiansen, F. G., Boserup, J., Buchardt, B., Guvad, C., Hansen, K., Koch, C. J. W., Jensenius, J., Nielsen, G. S., Nøhr-Hansen, H., Stouge, S., Thomsen, E. \& Østfeldt, P. 1989: Analytical programme and applied methods. In Christiansen, F. G. (edit.) Petroleum geology of North Greenland. Bull. Gronlands geol. Unders. 158, 21-26.

Ganz, H. H. \& Kalkreuth, W. 1987: Application of infrared spectroscopy to the classification of kerogen types and the evaluation of source rock and oil potentials. Fuel 66, 708711.
Ganz, H. H. \& Kalkreuth, W. in press: Infrared spectroscopical classification of kerogen type, thermal maturation, hydrocarbon potential and lithological characteristics in potential source and reservoir rocks. J. SE Asian Earth Sci.

Hansen, K. 1988: Preliminary report of fission track studies in the Jameson Land basin, East Greenland. Rapp. Grønlands geol. Unders. 140, 85-89.

Harpøth, O., Pedersen, J. L., Schønwandt, H. K. \& Thomassen, B., 1986: The mineral occurrences of central East Greenland. Meddr Grønland Geosci. 17, 139 pp.

Hurst, J. M., Scholle, P. A. \& Stemmerik, L. 1989: Submarine cemented bryozoan mounds, Upper Permian, Devondal, East Greenland. In Geldsetzer, H. J., James, N. P. \& Tebbutt, G. E. (edit.) Reefs - Canada and adjacent areas. Can. Soc. Petrol. Geol. Mem. 13, 672-676.

Jacob, H. 1985: Disperse, feste Erdölbitumina als Migrationsund Maturitätsindikatoren in Rahmen der Erdöl-/ErdgasProspektion. Eine Modellstudie in NW-Deutschland. Deutsche Gesellschaft Mineralölwissenschaft und Kohlechemie E.V., Forschungsbericht. 267, 54 pp.

Karlsen, D. A. 1987: Light hydrocarbon redistribution in shallow core from the Upper Permian Ravnefjeld Formation on the Wegener Halvø, East Greenland. Unpubl. cand. scient. thesis, University of Oslo, $152 \mathrm{pp}$.

Piasecki, S. 1985: Palynological evaluation of the regional thermal maturation of Carboniferous to Tertiary sediments in central East Greenland. Unpubl. GGU rep., 55 pp.

Piasecki, S. 1987: Leco/Rock-Eval screening analysis of the Upper Palaeozoic - Mesozoic sediments of Jameson Land, central East Greenland. Unpubl. GGU rep. Part I (text and figures) $61 \mathrm{pp}$., Part II (data and tables) $72 \mathrm{pp}$.

Stemmerik, L. 1982: Stratigrafi, sedimentologi og bassinudvikling i Øvre Perm aflejringsbassinnet syd for Kong Oscars Fjord, Østgrønland. Unpubl. cand. scient. thesis, University of Copenhagen, $200 \mathrm{pp}$.

Stemmerik, L., Scholle, P. A., Thomas, E., Amendolia, M., Henk, F. H. \& Uncini, G. 1989: Facies mapping and reservoir evaluation of the Upper Permian Wegener Halvø Formation in Wegener Halvø, East Greenland. Rapp. Grønlands geol. Unders. 145, 84-87.

Surlyk, F. 1983: Source rock sampling, stratigraphical and sedimentological studies in the Upper Palaeozoic of the Jameson Land basin, East Greenland. Rapp. Grønlands geol. Unders. 115, 88-93.

Surlyk, F., Hurst, J. M., Marcussen, C., Piasecki, S., Rolle, F., Scholle, P. A., Stemmerik, L. \& Thomsen, E. 1984a: Oil geological studies in the Jameson Land basin, East Greenland. Rapp. Grønlands geol. Unders. 120, 85-90.

Surlyk, F., Piasecki, S., Rolle, F., Stemmerik, L., Thomsen, E. \& Wrang, P. 1984b: The Permian basin of East Greenland. In Spencer, A. M. et al. (edit.) Petroleum geology of the North European margin, 303-315. London: Graham \& Trotman.

Surlyk, F., Hurst, J. M., Piasecki, S., Rolle, F., Scholle, P. A., Stemmerik, L. \& Thomsen, E. 1986a: The Permian of the western margin of the Greenland Sea - a future exploration target. In Halbouty, M. T. (edit.) Future petroleum prov- 
inces of the World. Mem. Am. Ass. Petrol. Geol. 40, 629659.

Surlyk, F., Piasecki, S. \& Rolle, F. 1986b: Initiation of petroleum exploration in Jameson Land, East Greenland. Rapp. Grønlands geol. Unders. 128, 103-121.
Thomsen, E., 1985: A coalification study of Upper Palaeozoic - Mesozoic deposits from central East Greenland. Unpubl. GGU rep. Part I (text) 55 pp., Part II (tables, figures, plates) $67 \mathrm{pp}$. 